$\square$ Anatomy $\square \quad$ Full paper

\title{
The Differences of the Functional-morphological Strategy between the First and Second Dorsal Fins of the Living Coelacanth (Latimeria chalumnae)
}

\author{
Hideki ENDO ${ }^{1,2)}$, Ayano OMURA ${ }^{2)}$, Takeo SAKAI ${ }^{3)}$, Takuya ITOU ${ }^{3)}$, Hiroshi KOIE ${ }^{4)}$, \\ Masamitsu IWATA ${ }^{5)}$ and Yoshitaka $\mathrm{ABE}^{5)}$ \\ 1) The University Museum, The University of Tokyo, Tokyo 113-0033, Japan \\ 2) Department of Global Agricultural Sciences, Graduate School of Agriculture and Agricultural Life Sciences, \\ The University of Tokyo, Tokyo 113-0033, Japan, \\ 3) Department of Preventive Veterinary Medicine and Animal Health, College of Bioresource Sciences, \\ Nihon University, Fujisawa, Kanagawa 252-8510, Japan, \\ 4) Department of Veterinary Physiology, College of Bioresource Sciences, Nihon University, \\ Fujisawa, Kanagawa 252-8510, Japan, \\ 5) Aquamarine Fukushima, Iwaki, Fukushima 971-8101, Japan
}

（2011 年 5 月 15 日受領, 2011 年 10 月 31 日採択）

\section{現生シーラカンス (Latimeria chalumnae) における第一・第二背鰖間の 機能形態学的戦略の相違}

\author{
遠藤秀紀 $^{1,2)}$, 大村文乃 ${ }^{2)}$, 酒井健夫 ${ }^{3)}$, 伊藤玩也 ${ }^{3)}$, 鯉江 洋 $^{4)}$, 岩田雅光 ${ }^{5)}$, 安部義孝 ${ }^{5)}$ \\ 1) 東京大学総合研究博物館 $=113-0033$ 東京都文京区本郷 7-3-1 \\ 2) 東京大学大学院農学生命科学研究科農学国際専攻 ₹ 113-8657 東京都文京区弥生 1-1-1 \\ 3）日本大学生物資源科学部獣医衛生学研究室 $=252-8510$ 神奈川県藤沢市亀井野 1866 \\ 4）日本大学生物資源科学部獣医生理学研究室 干 252-8510 神奈川県藤沢市亀井野 1866
}

5) アクアマリンふくしま † 971-8101 福島県いわき市小名浜字辰巳町 50

\begin{abstract}
The first and second dorsal fins of living coelacanths were studied using three-dimensional reconstructed images, while the sectional areas of the epaxial and hypaxial musculatures and the musculature related to the first and peculiar to the second dorsal fins were measured by image analyzing methods. The musculature related to the first dorsal fin was not enlarged to the lepidotrichia beyond the dorsal margin of the trunk; however, the fin rays consisting of lepidotrichia were supported by bone plate of the trunk. The two bones of the trunk supported the four bone elements of the second dorsal fin, in which the peculiar musculature was developed from the trunk area to the bone elements. The first dorsal fin may function as a passive stabilizer controlled by the relatively smaller musculature from the bone plate of the trunk and the mechanical articulation between the bone plate of the trunk and lepidotrichia. In contrast, the second dorsal fin represented an active generator of thrust during slow locomotion. We suggest that the active power generator of the sarcopterygian fin may be required in the second dorsal fin at the caudal region of the trunk, which possesses fewer epaxial and hypaxial muscles than the cranial region where the first dorsal fin is located.
\end{abstract}

Key words : Coelacanths, CT, Dorsal fin, Latimeria, Musculoskeletal system

Jpn. J.Zoo. Wildl. Med. 17(2) : 79-86, 2012

Two species of Latimeria belonging to the coelacanths have been considered as one of the living fossils. As the form of this taxon has not changed since the Cenozoic Era, the history of the discovery and records of Latimeria chalumnae, L. menadoensis and their related fossil species had great impacts on evolutionary biology [1-15]. Anatomical reviews of L. chalumnae have been published [16-18], since its description, especially pertaining to the origin of their four limbs, and the pectoral and pelvic fins have attracted the attention of many evolutionary morphologists. The two pairs of fins [16, 19-22] and basicranial structure [23, 24] have been morphologically detailed after comparison with the fossils as one of the Crossopterygii, Eustenopteron, and the earliest amphibians as Icthyostaga and Acanthostaga. However, because the locomotion mechanism of the two dorsal fins has not been shown to be associated with the origin of the four limbs, the first ray and second lobed dorsal fins have not been morphologically examined exhaustively. The reason for 
the existence of two morphologically different dorsal fins in sarcopterygii fishes such as Latimeria remains unclear. In this study, therefore, using computed tomography (CT), the internal structure of the first and second dorsal fins and the epaxial and hypaxial musculatures were observed and quantitatively analyzed to determine the functional significance in the coelacanths during a specific evolutionary stage.

\section{MATERIALS AND METHODS}

One frozen specimen 〔CCC (Coelacanth Conservation Council, Grahamstown, South Africa) Individual No: 213] of the Comoran coelacanth (L. chalumnae) was used for CT examinations. The specimen was obtained from Tanzania and has been stored in Aquamarine Fukushima. The body of the specimen was axially sectioned by CT (Toshiba Aquilion16: Toshiba Medical Systems, Japan) at $2 \mathrm{~mm}$ thickness without gap at $120 \mathrm{kV}$ and $200 \mathrm{mAs}$. Three-dimensional images were reconstructed from a series of CT sections by Voxel Transmission (Volume Rendering) techniques through an image analyzing system (AZE Virtual Place: AZE Corporation, Japan). Adequate thresholds were qualitatively selected and the axial, bilateral, and horizontal sections obtained from the three-dimensional reconstructed image were used to effectively visualize the regions of the dorsal fins and related axial musculatures. The software Image (NIH, USA) was used to measure the sectional areas of the epaxial and hypaxial musculatures and muscles peculiar to the two dorsal fins. We used 43 serial axial sections of $10 \mathrm{~mm}$ interval including the regions of the first and second dorsal fins for measurements of the musculature areas.

\section{RESULTS}

The three-dimensional reconstructed images of the whole

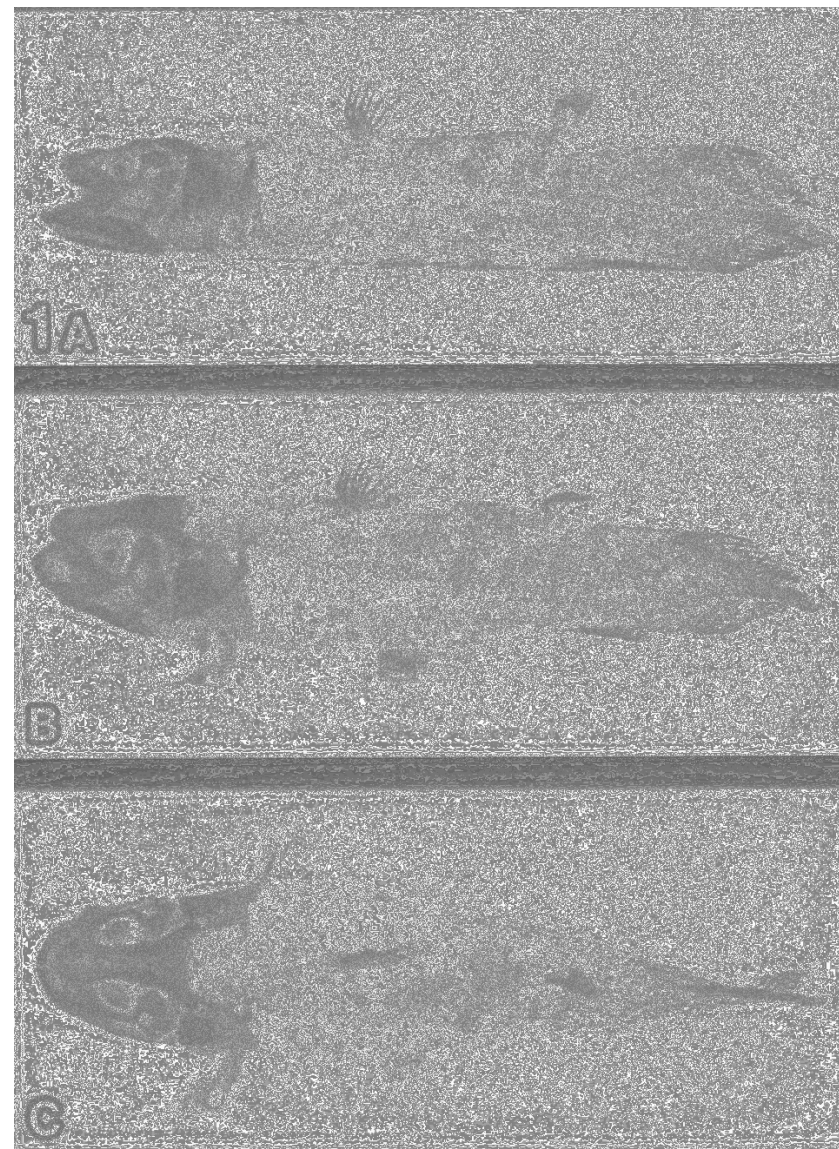

Fig. 1 The three-dimensional reconstructed images of the whole body. A : left lateral aspect, B : dorso-lateral aspect, $\mathrm{C}:$ dorsal aspect.

body of the specimen were axially rotated (Fig. 1). The total body length was $1190 \mathrm{~mm}$ from the reconstructed data. The lateral sections of the region including the two dorsal fins are

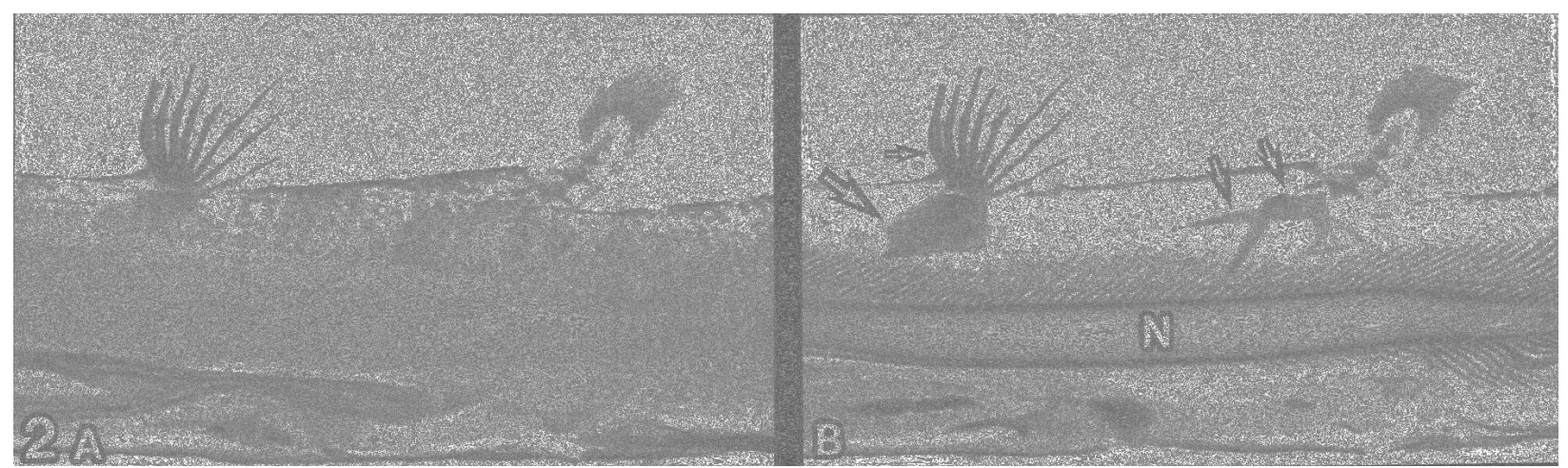

Fig. 2 Parasagittal (A) and sagittal (B) sections of the body. The lepidotrichia (small arrow) with eight pairs of fin ray is seen. The bone plate (large arrow) related to the first dorsal fin, and the two bones (intermediate arrows) connected to the second dorsal fin are shown. N, Notochord. Cranial direction at the left. 
Dorsal fins of living coelacanth

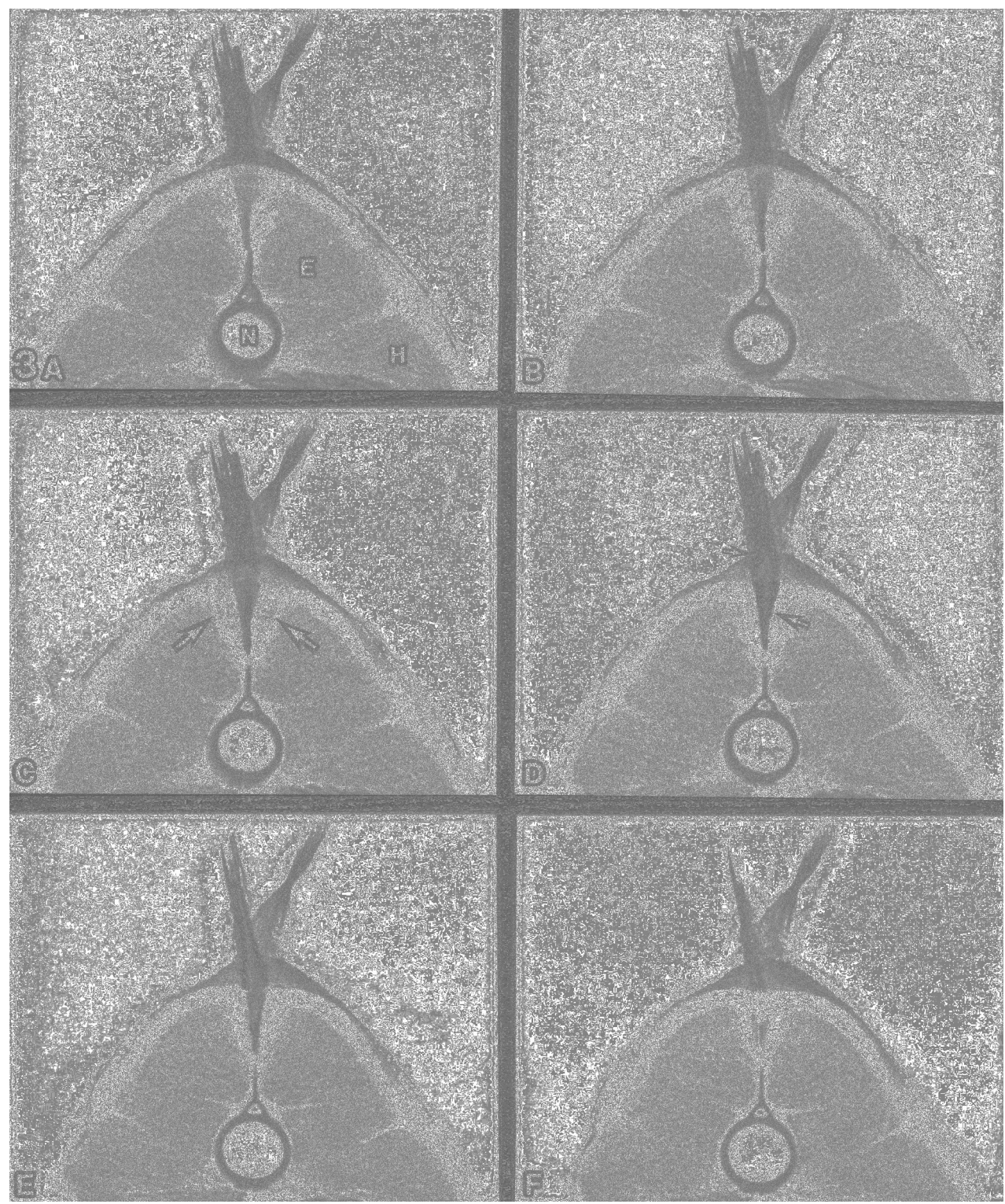

Fig. 3 The axial sections of the area of the first dorsal fin. The sections are arranged from the cranial (A) to the caudal (F) region with the longitudinal interval of $20 \mathrm{~mm}$. The musculature (large arrows) ran from the bone plate (intermediate arrow) to the lepidotrichia (small arrow). E, epaxial musculature. H, hypaxial musculature. N, notochord. Dorsal direction at the top.

shown (Fig. 2). The horizontal sections of the first (Fig. 3) and the second (Fig. 4) dorsal fins are arranged.

The first ray dorsal fin was equipped with the lepidotrichia, whereas the second lobed dorsal fin represented the sarcopterygian fin with substantial musculoskeletal elements (Fig. 2). The lepidotrichia of the first dorsal fin possessed eight pairs of fin ray. The first dorsal fin was supported by the bone plate along the sagittal plane (Fig. 2). Specialized attachment between the bone plate and the lepidotrichia of the first dorsal fin were confirmed; however, peculiar musculature was not observed even in the fin itself (Fig. 3). The musculature related to the fin ran from the bone plate to the basal area of the lepidotrichia. Although the musculature was confirmed around the bone plate related to the first dorsal fin, it was not enlarged to the fin beyond the dorsal margin of the trunk. The musculature directly attached to the bone plate in the area 


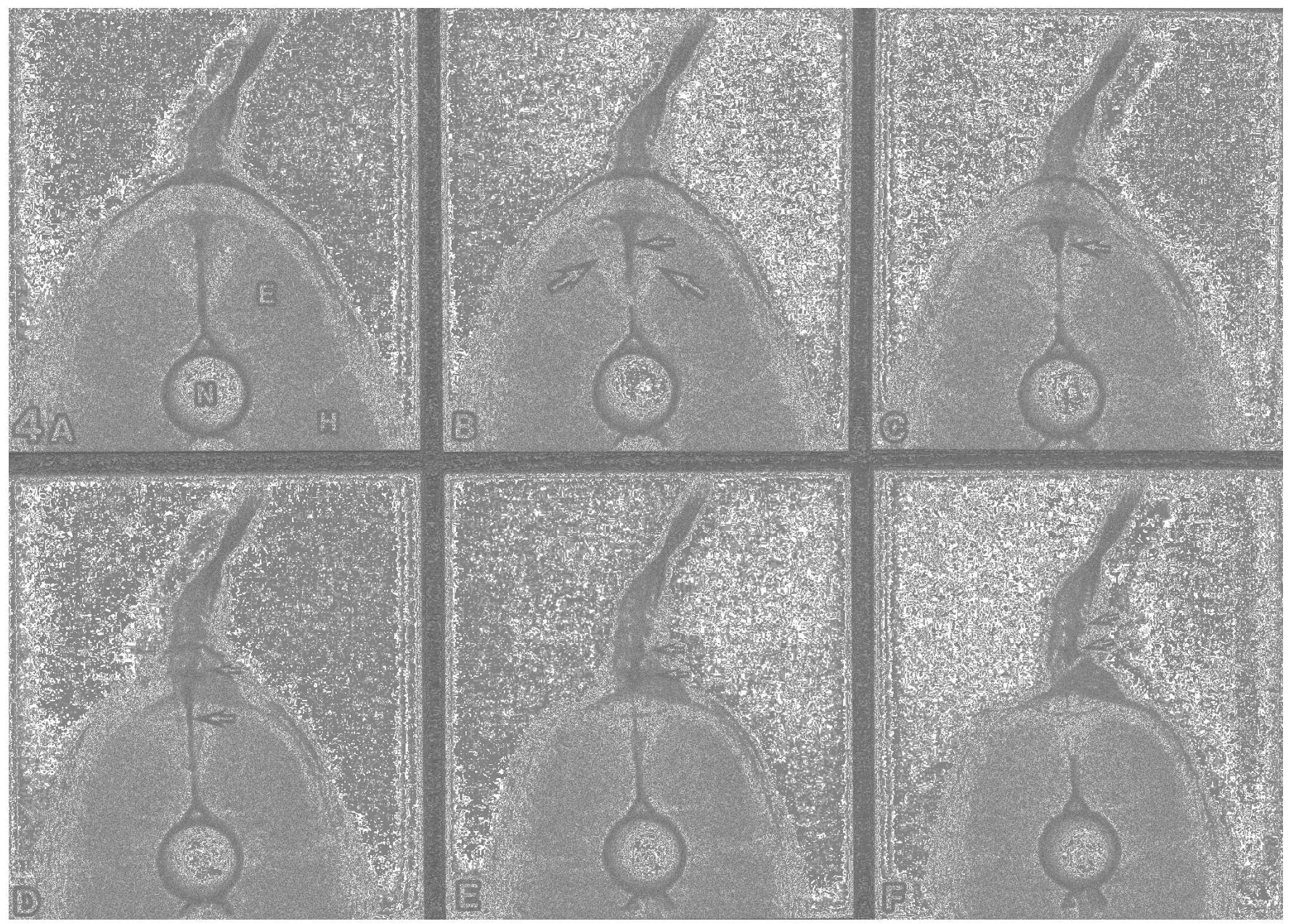

Fig. 4 The axial sections of the area of the second dorsal fin. The sections are arranged from the cranial (A) to the caudal (F) region with the longitudinal interval of $20 \mathrm{~mm}$. The musculature (large arrows) peculiar to the fin originates from the two bone plates (intermediate arrows) of the trunk and runs to the bone element (small arrows). E, epaxial musculature. H, hypaxial musculature. N, notochord. Dorsal direction at the top.

of the first dorsal fin was clearly separated from the epaxial musculature (Fig. 3). The musculoskeletal mechanism of the second dorsal fin consisted of thick musculature peculiar to this fin (Fig. 4). The muscles arose from of the two bones in the trunk and reached the distal area of the fin. The muscle bundle became thinner in the distal part of the fin; however connected each bone element to form an active locomotion apparatus.

Horizontal sections of the first dorsal fin are shown (Fig. 5). The lepidotrichia consisted of eight symmetrical fin rays in the first dorsal fin. Eight pairs of fin rays were bilaterally developed and dorso-caudally radiated. The lepidotrichia was articulated to the bone plate of the trunk. The musculature related to the first dorsal fin rose from the huge bone plate. It was adjacent to the dorso-medial surface of the epaxial musculature; however it was not morphologically connected to the median neural spine and the notochord.

The hard parts of the second dorsal fin consisted of four bone elements supported by the two bones of the trunk (Figs. 2 and 6). The caudal bone of the trunk showed a thick post and thinner ventral plate (Fig. 6). The thick musculature enveloped the four bone elements of the second dorsal fin. The musculature was not substantially related to the median neural spine and notochord; however, it originated from the two bones of the trunk and ran to the four bone elements of the fin.

The data of the sectional area of the musculatures are arranged from the cranial to caudal regions of the body (Table 1 and Fig. 7). The enlarged areas of the musculature related to the first dorsal fin were $411-544 \mathrm{~mm}^{2}$ in each side (Section 
Dorsal fins of living coelacanth

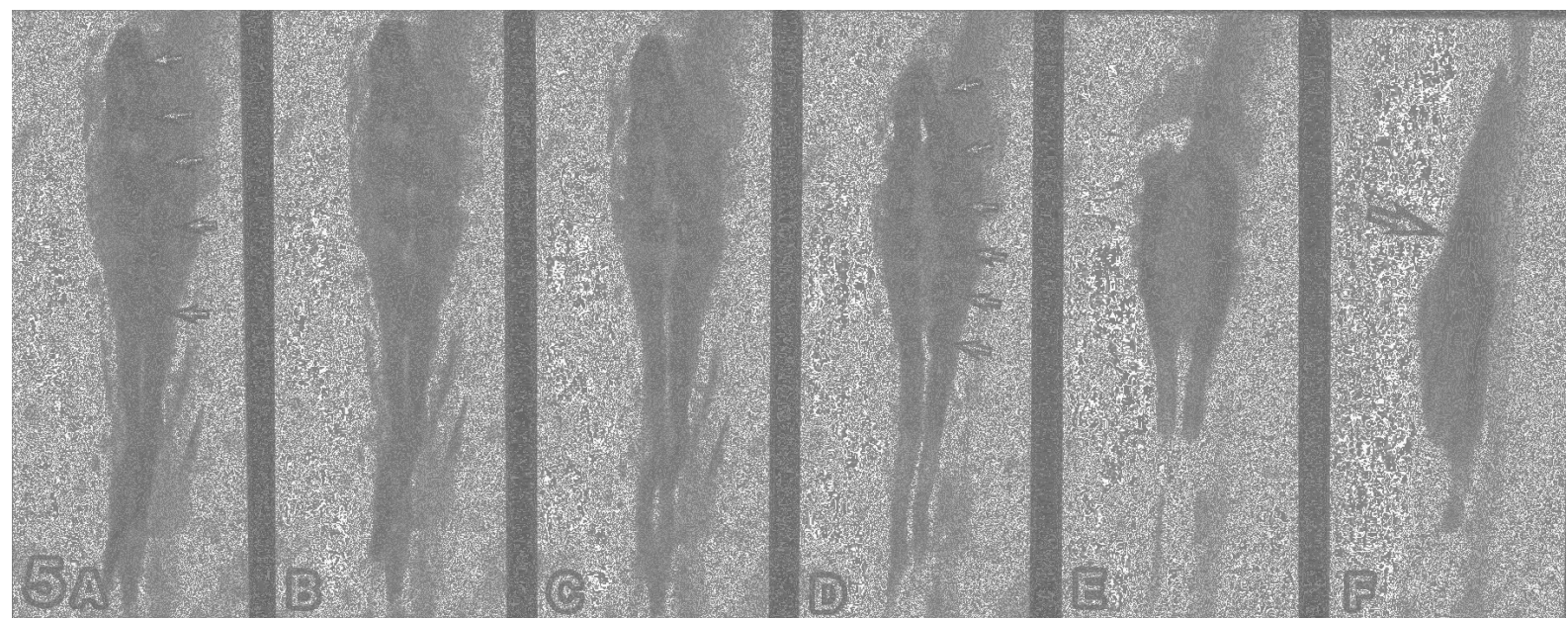

Fig. 5 The horizontal sections of the first dorsal fin. The sections are arranged from the dorsal (A) to the ventral (F) levels with the vertical interval of $20 \mathrm{~mm}$. The eight fin rays (small arrows) of the lepidotrichia are observed, whereas the bone plate (large arrow) is discerned. Cranial direction at the top.

Nos. 9-13), in which the areas of the epaxial musculature were about 4000-4800 $\mathrm{mm}^{2}$. Whereas the areas of the musculature peculiar to the second dorsal fin reached 423-739 $\mathrm{mm}^{2}$ (Section Nos. 36-40), the epaxial musculature in each side were approximately $3000-4100 \mathrm{~mm}^{2}$ in the same region (Table 1 , Figs. 7 and 8). The total areas of the musculature related to the first dorsal fin were 3982 and $4025 \mathrm{~mm}^{2}$, those peculiar to the second dorsal fin 4898 and $4113 \mathrm{~mm}^{2}$ in each side. The largest sections of the epaxial and hypaxial musculature were in the cranial region of the trunk; however, both axial musculatures rapidly decreased, as the sarcopterygian fin, such as the second dorsal fin, grew thicker (Table 1, Figs 3, 4, 7 and 8).

\section{DISCUSSION}

Since the enlarged musculature of the second dorsal fin originated from the two bone plates and attached to each bone element, this fin may have enabled the coelacanth to control the thrust from the caudal region of the body and to stabilize

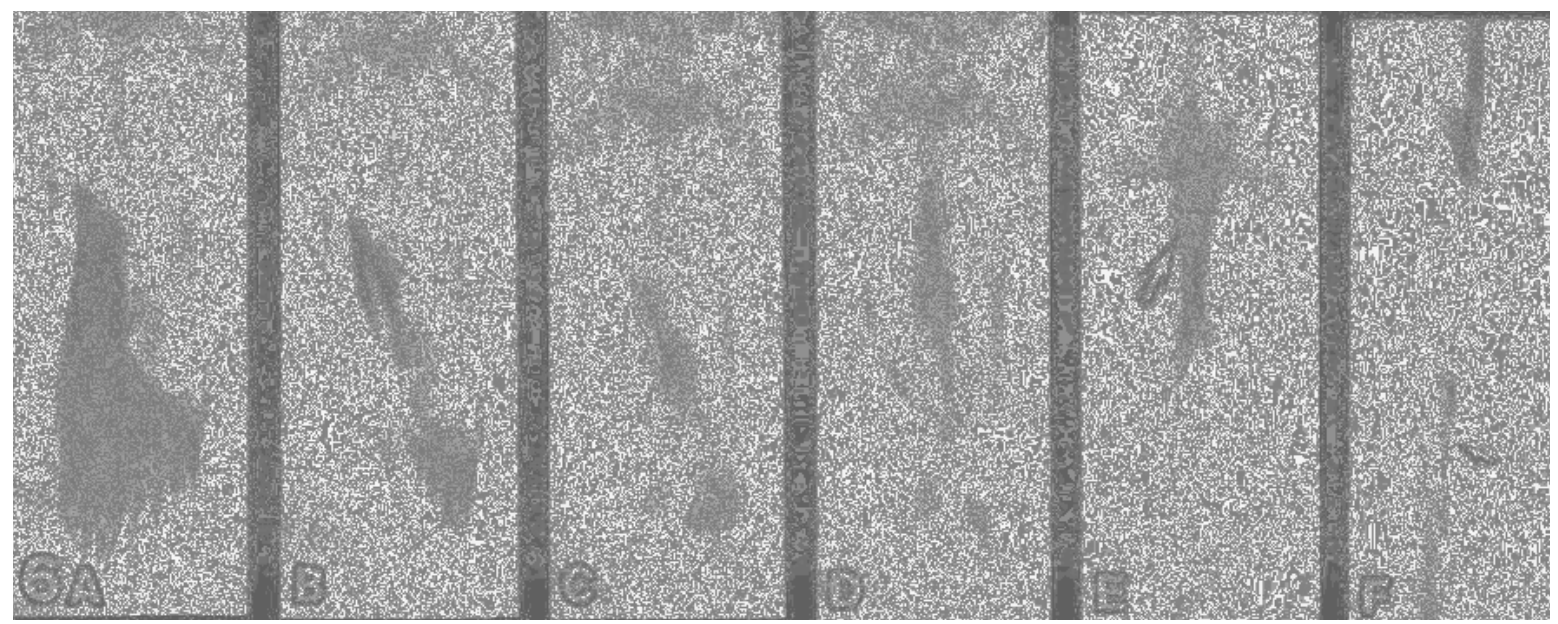

Fig. 6 The horizontal sections of the second dorsal fin. The sections are arranged from the dorsal (A) to the ventral (F) levels with the vertical interval of $25 \mathrm{~mm}$. The bone elements of the fin are observed in the sections of the fin (B, C and D). The two bones support the bone elements from the trunk side (E and $F)$. The caudal bone of the trunk consists of a thick post (large arrow) and thinner ventral plate (small arrow). Cranial direction at the top. 
Hideki ENDO et al.

Table 1 Axial sectional area $\left(\mathrm{mm}^{2}\right)$ of each musculature

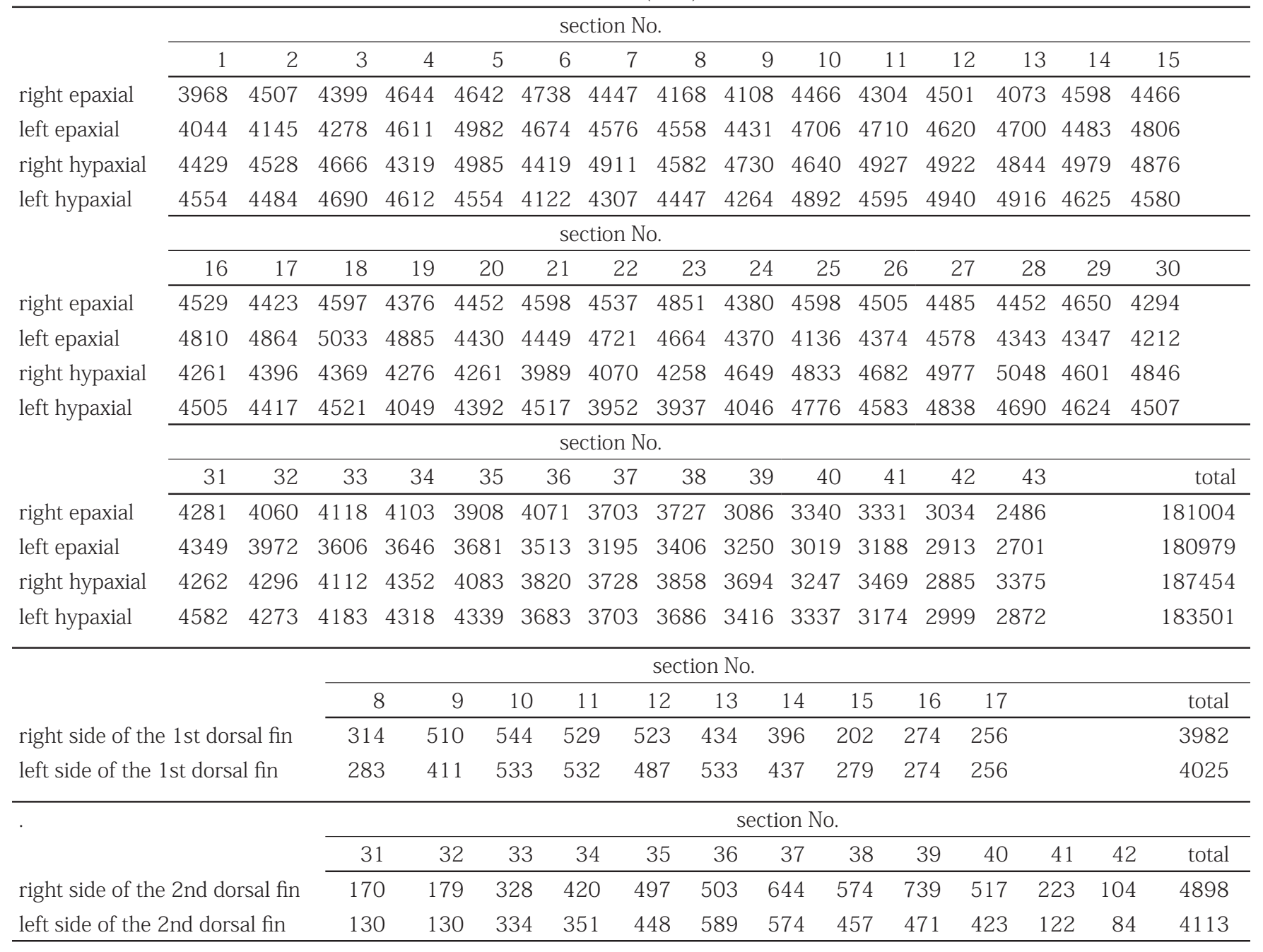

the trunk during slow locomotion. The two dorsal fins have not been functional-morphologically detailed in Latimeria, although the field observation of the living Latimeria [25] and a comparative paleontological study [26] mainly dealt with the second dorsal fin. The second dorsal fin, together with the anal fin may help in generating thrust coordinated rotating movement around the long axis, and thus change the mode of slow locomotion [26]. Since the slow locomotion at least in Latimeria species is produced by flexible movement of the trunk and the sculling of the second dorsal and anal fins, the developments of the axial musculature and the second dorsal fin-related musculature are noteworthy.

On the musculatures related to the first and peculiar to the second dorsal fins, the axial sectional area was noticeable. The total areas were larger in the musculature peculiar to the second dorsal fin than that related to the first dorsal fin. It indicated the strong power of the stroke of the second dorsal fin. As the region including the second dorsal fin had a smaller sectional area of axial musculatures than that of the first dorsal fin, we suggest that the musculature peculiar to the second dorsal fin may act as one of the important thrust generators in caudal region of the body.

In contrast, the musculature related to the first dorsal fin appeared relatively smaller than the thick axial musculature in cranial region. In addition, the musculature was not distally extended in the first dorsal fin. These findings suggest that the second dorsal fin may contribute to the slow locomotion of the coelacanths as one of the main active thrusters [25], whereas the first dorsal fin may act as an additional passive stabilizer $[16,27]$. We suggest that the strong power generator of the sarcopterygian fin such as second dorsal and anal fins may be required in the caudal region of the trunk, which possesses 


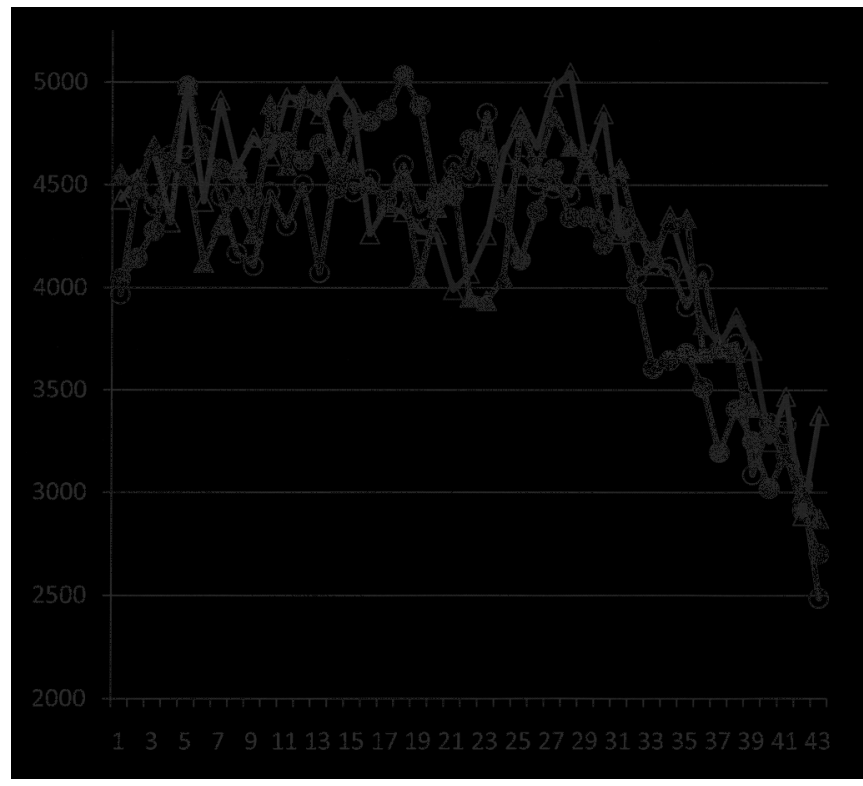

Fig. 7 Axial sectional areas of the axial musculatures. Horizontal axis, the section number from cranial to caudal region. Vertical axis, areas (square millimeter). Open circles, right epaxial musculature. Solid circles, left epaxial musculature. Open triangles, right hypaxial musculature. Solid triangles, left hypaxial musculature.

fewer quantity of the axial musculatures than in the cranial region in which the first dorsal fin is positioned. Considering, at least qualitatively, the sectional area of the axial musculatures, it was consistent that Eustenopteron possessed the second dorsal and anal fins in the portion of the trunk that rapidly thinned [19, 20].

Previously, the CT and/or MRI examinations of living Latimeria species have been published [21, 27]. The morphological relationships between external and internal structures can be easily observed in coelacanths; therefore quantitative analyses using CT data will have added importance in the functional-morphology of the coelacanths. In this study, the morphologically artifact might be caused because of freezing in a degree; however, the dorsal area including the two fins did not appear to have been artificially changed in this specimen.

Ecological and physiological studies have been published on Comoran Latimeria [25, 28-31]. We believe that the field observations and physiological approaches will help in elucidating the functional relationships between the dorsal fin structure and the slow locomotion characteristic of the coelacanths, in addition to the purely morphological observations. Since our team is collecting the movie data on

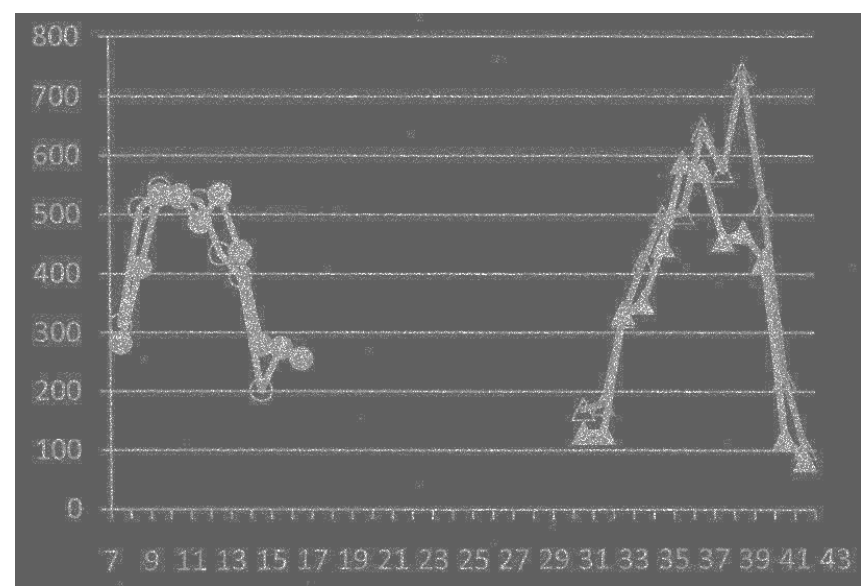

Fig. 8 Axial sectional areas of the musculature related to the first and peculiar to the second dorsal fins. Horizontal axis, the section number. Vertical axis, areas (square millimeter). Open circles, right musculature related to the first dorsal fin. Solid circles, left musculature related to the first dorsal fin. Open triangles, right musculature peculiar to the second dorsal fin. Solid triangles, left musculature peculiar to the second dorsal fin.

the action of the dorsal fins, the data will contribute to the functional analysis of the independent roles of each dorsal fin.

\section{ACKNOWLEDGEMENTS}

We thank the staff of Aquamarine Fukushima for their help and encouragement in this study. This study was financially supported by the Grant-in-Aids for Scientific Research nos. 21370033, 21658103, 22405002 from the Ministry of Education, Science and Culture, Japan.

\section{要 約}

現生シーラカンスの第一および第二背鯺を三次元復構画像を 用いて検討し, 軸上筋と軸下筋, 第一背鰙に関連する筋肉, 第 二背鮨固有の筋肉の断面積を画像解析手法により計測した。第 一背鯺に関連する筋肉は体幹の背側端を超えて鱗状鯺条まで伸 長することはなかった。しかし, 鱗状鰙条からなる放射した鮊 は体幹部の骨性の板によって支持されていた。第二背鯺では, 体幹部の 2 つの骨が鰖の 4 つの骨格要素を支持し，その 4 つ の骨の周囲には, 体幹部から固有の筋層が発達していた。第一 背鰙は，体幹部の骨質の板から伸びる比較的小さな筋肉と，体 幹部の骨質の板と鱗状鯺条の間の機械的な関節によって制御 される, 受動的な安定板として機能していると推察された。対 照的に第二背鯺は, 速度の遅い運動時に積極的な推進力を生み 
出す装置となっていることが示唆された。第一背鯺が位置する 体幹前方と比べて軸上筋と軸下筋が減少する体幹後方において は, 肉鯺類の鯺による推進力の発生は, 第二背鯺に要求される 機能であることが推測された。

キーワード：シーラカンス, CT, 背鰖, Latimeria, 筋骨 格系

\section{REFERENCES}

1. Smith JLB. 1939. A living fish of Mesozoic type. Nature 143: 455-456.

2. Smith JLB. 1940. A living coelacanthid fish from South Africa. Trans Roy S Afr 28: 1-106.

3. Smith JLB. 1953a. The second coelacanth. Nature 171: 99-101.

4. Smith JLB. 1953b. Problems of the coelacanth. S Afr J Sci 49: 279-281.

5. Anthony J. 1980. Évocation des travaux français sur Latimeria notamment depuis 1972. Proc R Soc Lond B 208: 349-367.

6. Balon EK, Burton MN, Fricke, H. 1988. A fiftieth anniversary reflection on the living coelacanth, Latimeria chalumnae: some new interpretations of its natural history and conservation status. Env Biol Fish 23: 241-280.

7. Thomson KS. 1991. Living Fossil: The Story of the Coelacanths. W. W. Norton, New York. 252 pp.

8. Erdmann MV, Caldwell RL, Moosa MK. 1998. Indonesian "king of the sea" discovered. Nature 395: 335.

9. Erdmann MV. 1999. An account of the first living coelacanth, Latimeria chalumnae, with comments on trends in catches. Env Biol Fish 54: 439-443.

10. Erdmann MV, Caldwell RL, Jewett SL, Tjakrawidjaja A. 1999. The second recorded living coelacanth from north Sulawesi. Env Biol Fish 54: 445-451.

11. Forey PL. 1998. A home from home for coelacanths. Nature 395: 319-320.

12. Holder MT, Erdmann MV, Wilcox TP, Caldwell RL, Hillis DM. 1999. Two living species of coelacanths? Proc Natl Acad Sci USA 96: 12616-12620.

13. Pouyaud L, Wirjoatmodjo S, Rachmatika I, Tjakrawidjaja A, Hadiaty R, Hadie W. 1999. A new species of coelacanth. C R Acad Sci III 322: 261-267.

14. Clement G. 2005. A new coelacanth (Actinistia, Sacopterygii) from the Jurassic of France, and the question of the closest relative fossil to Latimeria. J Vert Paleontol 25: 481-491.

15. Inoue JG, Miya M, Venkatesh B, Nishida M. 2005. The mitochondrial genome of Indonesian coelacanth Latimeria menadoensis (Sacropterygii: Coelacanthiformes) and divergence time estimation between the two coelacanths. Gene 349: 227-235

16. Millot J, Anthony J. 1958. Anatomie de Latimeria chalumnae. 1. Squelette, Muscles et Formations de Soutien. C. N. R. S., Paris. 122 pp.

17. Millot J, Anthony J. 1965. Anatomie de Latimeria chalumnae. 2. Systè me Nerveux et Organes des Sens. C. N. R. S., Paris. 125 pp.

18. Millot J, Anthony J, Robineau D. 1978. Anatomie de Latimeria chalumnae. 3. Appreil Digestif - Appareil Respiratoire - Apparail Urogé nital - Glandes Endocrines - Appareil Circulatoire - Téguments - Écailles - Conclusions Générales. C. N. R. S., Paris. 198 pp.

19. Jarvik E. 1980. Basic Structure and Evolution of Vertebrates. Vol. 1 Academic Press, New York. 575 pp.

20. Jarvik E. 1981. Basic Structure and Evolution of Vertebrates. Vol. 2. Academic Press, New York. 337 pp

21. Suzuki N, Hamada T. 1990. Structure of pectoral and anal fin of coelacanth revealed by noninvasive imaging techniques. Sci Pap College Arts Sci Univ Tokyo 40: 79-94.

22. Coates MI, Jeffery JE, Ruta M. 2002. Fins to limbs: what the fossils say Evol Dev 4-5: 390-401

23. Bemis WE, Northcutt, RG. 1991. Innervation of the basicranium muscle of Latimeria chalumnae. Env Biol Fish 32: 75-97.

24. Bjerring HC. 1993. Yet another interpretation of the coelacanthiform basicranial muscle and its innervation. Acta Zool 74: 289-299.

25. Fricke H, Reinicke O, Hofer H, Nachtgall W. 1987. Locomotion of the coelacanth, Latimeria chalumnae, in its natural environment. Nature 329: 331-333.

26. Forey PL. 1991. Latimeria chalumnae and its pedigree. Env Biol Fish 32: 75-97.

27. Schultze H-P, Cloutier R. 1991. Computed tomography and magnetic resonance imaging studies of Latimeria chalumnae. Env Biol Fish 32: 159-181.

28. Smith CL, Rand CS, Schaeffer B, Artz JW. 1975. Latimeria, the living coelacanth, is ovoviviparous. Science 190: 1105-1106.

29. Hughes GM. 1976. On the respiration of Latimeria chalumnae. Zool J Linn Soc 59: 195-208.

30. Fricke H, Hissmann K, Schauer J, Reinicke O, Kasang L, Plante R. 1991 Habitat and population size of the coelacanth Latimeria chalumnae at Grand Comoro. Env Biol Fish 32: 287-300.

31. Fricke H, Plante R. 1988. Habitat requirements of the living coelacanth Latimeria chalumnae at Grande Comore, Indian Ocean. Naturwissenschaften 75: 149-151. 